\title{
Using the Net Present Value Rule to Make Value-Creating Investment Decisions
}

\author{
Xu Hui \\ School of Business management \\ Tong Hua Normal University \\ Tong Hua, China \\ dbcy9999@163.com
}

\begin{abstract}
At present, most of the researches on net present value are focused on single objective cases. This paper discusses net present value problem with upper level multiobjective optimization. In order to solve the problem efficiently, we present a genetic algorithm using interpolation. According to the NPV rule, if the investment has a positive (negative) NPV it creates (destroys) value and should be undertaken (rejected) .The NPV rule is a good investment decision rule because it adjusts the investment's expected cash flows for both their timing and risk and has the convenient property of being additive. Most important is the capacity of the NPV method to evaluate the valuecreating potential of an investment proposal. In addition, the NPV of an investment proposal is an estimate of the current value the proposal will create or destroy if undertaken.
\end{abstract}

Keywords-net present value; investment decisions; capital investment process; capital budgeting; objective optimization

\section{INTRODUCTION}

The steps involved in applying the NPV [1-3] rule to evaluate an investment proposal are summarized in this paper. Tow inputs are required to calculate a project's NPV: (1) the expected cash-flow stream that the project will generate over its useful life and (2) the appropriate cost of capital that reflects the risk of the expected cash-flows. The cost of capital is the rate at which the project's future cash flows need to be discounted to compare their present value with the investment cost. This paper shows how to estimate a project's expected cash-flow stream, and this paper shows how to estimate its appropriate risk-adjusted cost of capital.

\section{DISCUSSED PROBLEMS}

Wherever Times is specified, Times Roman or Times New Roman may be used. If neither is available on your word processor, please use the font closest in appearance to Times. Avoid using bit-mapped fonts if possible. TrueType 1 or Open Type fonts are preferred. Please embed symbol fonts, as well, for math, etc.

One of the most important decisions a manager can make is the capital investment decision. This key decision requires spending cash now to acquire long-lived assets that will be a source of cash flows in the future. A successful capital investment program [4-5] will contribute positively to the firm's financial performance for many years. The firm's managers will be commended for their skills in identifying potentially successful projects and carrying them to fruition (we use the terms project, investment, and performance proposal interchangeably). If the capital investment program fails, suppliers of funds-the shareholders and creditors-could lose confidence in the ability of the firm's managers to make good investment decision and may became reluctant to provide additional funds in the future.

What is a good investment decision? From a financial management perspective, a good investment decision is a decision that raises the current market value of the firm's equity, thereby creating value for the firm's owners. An investment decision can have other objectives, but managers who ignore the value-creation objective may jeopardize both the future of there firms and their employment prospects. The value-creating investment decision must raise market value, not book value or accounting profit. Shareholders cash in on their investment by selling their shares for cash, not for accounting profits.

Capital budgeting involves comparing the amount of cash spent today on an investment with the cash flows are spread over time, they cannot be compared directly with cash spent today. Recall that a dollar received later is worth less than a dollar received earlier cash inflows. This preference for "early cash" is called the time value of money.

Discounting is the mechanism used to convert future cash flows into their equivalent value today. In other words, discounting adjusts future cash flows for the time value of money. For example, a riskless cash inflow of $\$ 1,100$ available one year form now is worth $\$ 1,000$ today, if the firm can earn 10 percent on cash deposited now in a risk-free saving account. (If a firm deposits $\$ 1,000$ today in a bank that offer 10 percent, it will have $\$ 1,100$ in one year.)The $\$ 1,000$ is the present value, or discounted value, of the $\$ 1,100$ of future cash inflow at a discount rate of 10 percent. This paper shows how to calculate the discounted value of a cash flow occurring at any date in the future.

Apart from the timing issue, the risk associated with future cash flows is also an issue. Future cash flows are called discounted cash flow (DCF) models. This paper presents the net present value (NPV) model and briefly examines a useful variation, the profitability index (PI) .This paper presents and compares other DCF and non-DCF model and concludes that the NPV approach to investment appraisal is superior to alternative methods. 
There are two critical elements in a DCF valuation. One is the identification and measurement of the project's expected cash flows and the other is the estimation of the appropriate discount rate required to calculate the project's present value. This paper is devoted entirely to the first issue and this paper deals with the second. In this paper, we assume that both the investment's expected cash-flow stream and its appropriate discount rate are known and show how to calculate the investment's NPV. We also explain what NPV measures and how it should be interpreted.

The valuation of a project is a critical element in the capital investment process, but it is not the only one. Thus, we review the major steps involved in a capital investment decision before we explain how to perform an NPV analysis. After reading this paper, you should understand the following:

- The major steps involved in a capital budgeting decision

\begin{tabular}{|c|c|c|c|}
\hline $\begin{array}{l}\text { Type of investment } \\
\text { • Required } \\
\text { investment } \\
\text { - Replacement } \\
\text { investment } \\
\text { - Expansion } \\
\text { investment } \\
\text {-Diversification } \\
\text { investment }\end{array}$ & $\begin{array}{c}\text { Input } \\
\text { •Expected cash-flow } \\
\text { stream } \\
\text {-Discount rate }\end{array}$ & $\begin{array}{c}\text { Decision rule } \\
\text { - Net present value } \\
\text { - Profitability index } \\
\text { - Internal rate of } \\
\text { return } \\
\text { - Payback period }\end{array}$ & $\begin{array}{l}\text { Performance evaluation } \\
\text { - Monitor the magnitude and } \\
\text { timing of cash flows } \\
\text { - Check it the project still } \\
\text { meets the selection criterion } \\
\text { - Decide on continuation or } \\
\text { abandonment } \\
\text { - Review previous steps if } \\
\text { failure rate is high }\end{array}$ \\
\hline
\end{tabular}

Figure 1. The Capital Investment Process

Identified investment proposals must then be evaluated financially. The inputs required for the financial evaluation of a project include. (1) the estimation of its useful life; (2) the estimation of the cash flows the project is expected to generate over that useful life; and (3) the appropriate discount rate require to calculate the present value of the project's expected cash-flow stream. Estimating the parameters required for the financial analysis of a proposed investment is not an easy task; these estimation procedures are explained in detail in this paper (cash flows) and appropriate discount rate.

Proposals are usually classified by how difficult it is to estimate the key parameters needed for financial evaluation. Required investments are those the firm must make to comply with safety, health, and environmental regulations. In this case, managers want to know whether the present value of the cash expenses needed to comply with the regulations is greater than the cost of closing down. If it is, the project should be abandoned. Estimating such expenses should not be too complicated because, in most case, they are already specified by the regulatory authorities. Replacement investments are essentially costsaving projects that do not generate extra cash inflows. Their future cash benefits (basically cash savings) consist of reduction in anticipated costs that managers can identify with relative ease. Financial evaluation for expansion investments is more challenging because these projects
- How to calculate the present value of a stream of future cash flows

- The NPV rule and how to apply it to investment decisions

-Why a project's NPV is a measure of the value it creates

-How to use the NPV rule to choose among projects of different sizes or different useful lives

\section{THE CAPITAL INVESTMENT PROCESS}

The capital investment decision, also called the capital budgeting decision or capital expenditure decision, involves steps that are summarized in Figure 1.The process is initiate when the firm identifies business opportunities that can be translated into potentially valuable investment proposals. This is arguably the most important step in the generation of ideas and the uncovering of opportunities that could lead to successful long-term investments. require the firm to estimate the addition sales revenues, margins, and working capital that the expansion is expected to generate. Finally, financial evaluation for diversification investments is usually the most difficult. The cash flows these proposals are expected to generate are probably the hardest to forecast because the firm will enter an industry it does not know as well as its own.

After the proposal's financial parameters have been estimated, an investment criterion should be applied to decide whether the proposal will be accepted or rejected. This paper examines the net present value (NPV) rule in detail and the profitability index briefly. This paper looks at other popular selection criteria, such at the internal rate of return and the payback period, and discusses the profitability index in more detail.

\section{APPLYING THE NET PRESENT VALUE TO A CAPITAL INVESTMENT DECISION}

Applying the NPV rule to a capital expenditure decision is a straightforward exercise assuming that the entire project is expected to generate over its anticipated useful life and the cost of capital applicable to the investment under consideration. After these inputs are estimated, the present value of the project's stream of expected cash flows is calculate by discounting the cash flows at the project's cost of capital. Then, the project's 
initial cash outlay is subtracted from this present value to find the project's NPV is negative, the project is rejecting. We use an example to explain the procedure.

Sunlight Manufacturing Company (SMC) has been successfully producing and selling various types of electrical equipment for the last twenty years and is considering adding a new product, a designer desk lamp, to its existing product line. The firm would have to spend $\$ 2,360,000$ now to launch the new product, which is expected to be obsolete after five years. The investment is expected to generate an annual net cash flow of $\$ 832,000$ at the end of its first year, $\$ 822,000$ at the end of its second year, $\$ 692,000$ at the end of its third year, $\$ 554,000$ at the end of its fourth year, and a terminal net cash flow of $\$ 466,000$ at the end of its fifth year. The terminal cash flow includes the estimated resale value of any equipment used to manufacture the product; net of any liquidation cost. The project's estimated cost of capital is 7.6 percent. Should SMC launch the new product? To answer this question, we need to find the project's NPV.

First, the present value of each expected cash flow is calculated by multiplying it by its corresponding discount factor at the cost of capital of 7.6 percent (see Figure 1 Part I). Then, the initial cash outlay of $\$ 2,360,000$ is subtracted from the total present value of the project's expected cashflow stream to obtain the project's NPV:
NPV
(New
project
at
$7.6 \%)=$

$\$ 2,360,000+\$ 2,775,083=\$ 415,083$

The project's NPV is positive, so SMC should launch the designer desk lamp.

As you may have already noticed, the computation of NPVs for multiple-period project can be tedious. Fortunately, computer-based spreadsheets can make the task of computing NPVs quite easy. We show in Part II of Figure 1 how Microsoft Excel ${ }^{T M}$ can be used to compute the NPV of the designer desk lamp project. Commands are similar for other types of spreadsheet programs. Note also that most electronic financial calculators have several financial functions, including an NPV function. To use this function, simply enter the cash-flow values starting with the initial cash outlay and ending with last period cash flow. Then, enter the investment's cost of capital and press the NPV key. The calculator will compute the present value of the expected cash-flow stream and provide the project's NPV. You can also calculate NPV using the present value of $\$ 1$ paid or received at the end of any period up to twenty periods and at discount rates ranging from 1 to 20 percent. A far more complex and challenging task is the estimation of the inputs required to perform this calculation, namely, the project's expected cash-flow stream and its corresponding cost of capital.

\section{WHY THE NPV RULE IS A GOOD INVESTMENT RULE}

The NPV rule is a desirable investment decision [6-7] rule because, as discussed in this section, it has the following properties:

It is a measure of value creation: when the project's NPV is positive, the project creates value, and when it is negative, the project destroys value flows
It adjusts for the risk of the project's expected cashflows

It is additive

The first three properties are essential for any selection criterion used to decide whether to accept or reject a capital investment. In this paper, the comparisons of the NPV rule to alternative selection criteria are based on these important properties.

Although a project with a positive NPV is expected to create value, NPV does not provide any indication about the source of value creation. Firms can generate positive NPV projects and create value for the firm's owners for many reasons. The firm may have creative managers supported by a superior workforce. It may hold a strong position in a product or service market that makes it difficult for new entrants to compete on an equal footing. More important, some projects cannot be easily replicated by competitors, either because they require expertise that is specific to the firm or because they are protected by patents. For these reasons, a firm may be able to generate cash flows from some of its investments that have present values higher than the cost of investing in these projects.

\section{LIMITATIONS OF THE PRESENT VALUE CRITERION}

Although the NPV criterion [8] can be adjusted to deal with particular cases, such as the comparison of two projects of unequal size or unequal life spans, in other cases, the required adjustments to the NPV criterion are far too complex to be easily implemented. In most cases, these situations arise because the NPV criterion is a take-it-orleave-it rule that is based only on the information available [9-10] at the time the NPV is estimated. Hence, the NPV criterion ignores the opportunities to make changes to the project as time passes and more information becomes available. NPV is estimated from the stream of expected cash flows generated by the proposal and discounted at the project's cost of capital, which depends on the project's risk. The estimation of both the cash flows and their corresponding cost of capital depend on information available at the time NPV is calculated. This information involves factors such as the marketability of the product, its selling price, the risk of obsolescence, the technology used in manufacturing the product, and the economic, regulatory, and tax environments. A project that can be adjusted easily and inexpensively to significant changes in these factors will contribute more to the value of the firm than indicated by its NPV. It will also be more valuable than an alternative proposal with the same NPV that cannot be altered as easily and as cheaply. A project's flexibility, that is, the ability of a project to adjust to changing circumstances, is usually described by managerial options, which can be exercised to alter a project during its useful life.

The option to switch technologies and the option to abandon a project are embedded in most investment projects. However, these are not the only managerial options. Managers have many opportunities to enhance the value of an investment during its lifetime as circumstances change. A counterpoint to the option to abandon a project is the option to expand the project. For example, suppose the designer desk lamp is a big winner and the project needs to be expanded to meet increased demand. 
Regardless of the machine used to manufacture the lamps, SMC's management will have the option to expand the production line. But, contrary to the previous cases, it is not clear that the value of this option will be different for different machines because there is no reason to believe that it will be easier to increase the production of lamps with one machine rather than with the other one. However, this is not always the case, and a project that can be expanded is worth more than a project that cannot. An investment can usually be postponed, so another important managerial option is the option to defer an investment. This kind of option is particularly valuable in the mining and oil extraction industries where the output (mineral or oil) prices are particularly volatile. For example, the NPV of an oil reserve may be negative, given the current market expectations about the future price of oil. However, because the development of the reserve can be postponed, sometimes for many years, the capital expenditures needed to start the extraction of oil can be deferred until the market prices rise. And the more volatile the oil prices, the higher the chance that the NPV of the reserve will become positive, and the higher the value of the option to defer the development of the reserve.

In the absence of practical and simple ways to value these options, our advice is to remember that an investment decision should not be based on a single number - that is, its NPV. Before arriving at a decision, managers should conduct a sensitivity analysis to identify the most salient options embedded in the project, attempt to value them as we did for the abandonment option, and exercise sound judgment. Options embedded in a project are either worthless or have a positive value. Thus, the NPV of a project will always underestimate the value of an investment project. The larger the number of options embedded in the project and the higher the probability that the value of the project is sensitive to changing circumstances, the greater the value of these options and the higher the value of the investment project.

\section{SUMMARY}

After these inputs have been estimated, a financial calculator or any computer equipped with a spreadsheet application can compute the project's NPV. If the NPV is positive, the project creates value and should be undertaken. The present value of its future cash-flow stream is expected to more than compensate for the investment cost. If the project's NPV is negative, the project destroys value and should be rejected. In this case, the present value of its future cash-flow stream is not expected to cover the investment cost.

The NPV rule can be used to choose among projects with different initial size or different life spans. If a firm has a limit on the amount of funds its can invest in new projects, it may not be able to undertake all available positive NPV projects. If the alternative projects have different initial cash outlays (different sizes), then the project's profitability index can be used to select the combination of projects that would create the most value. However, if the constraint on the availability of funds is imposed every year, rather than just during the initial year, the profitability index may lead to suboptimal investment decisions. If projects have unequal life spans, the comparison should be made between sequences of projects of the same duration. The calculations for this comparison are easier if the projects' annuity-equivalent cash-flows are compared. The project with the lowest annuity-equivalent cost or the highest annuity-equivalent benefit should be selected.

Most projects have managerial options, options to change course after the project is launched, which are ignored in standard NPV analysis. The added value provided by these options is difficult to estimate. Although sensitivity analysis is not a perfect substitute, it can identify the most critical options embedded in a project, this providing valuable information for the final decision to accept or reject.

\section{ACKNOWLEDGMENT}

This work was supported by the Project of Education Department of Jilin Province (Grant No.2014388) and by the Doctor Support Project of Tong Hua Normal University under Grant No.201412.

\section{REFERENCES}

[1] Christian Gollier, "Expected net present value, expected net future value, and the Ramsey rule," Journal of Environmental Economics and Management, Vol. 59, pp. 2142-2148, March 2010.

[2] Tsu-Pang Hsieh, Chung-Yuan Dye, Liang-Yuh Ouyang, "Determining optimal lot size for a two-warehouse system with deterioration and shortages using net present value," European Journal of Operational Research, Vol.191, pp. 182-192, 16 November 2008.

[3] Mario Rese, Markus Karger, Wolf-Christian Strotmann, "The dynamics of Industrial Product Service Systems (IPS2) - using the Net Present Value Approach and Real Options Approach to improve life cycle management," CIRP Journal of Manufacturing Science and Technology, Vol.1, pp. 279-286, 2009.

[4] Feroz Kabir Kazia, Joshua A. Fortmana, Robert P. Anexa, David D. Hsub, Andy Aden, Abhijit Dutta, Geetha Kothandaraman, "Techno-economic comparison of process technologies for biochemical ethanol production from corn stover," Fuel, Vol.89, Supplement 1, pp. S20-S28, 1 November 2010.

[5] Ming Yang, William Blyth, Richard Bradley, Derek Bunn, Charlie Clarke, Tom Wilson, "Evaluating the power investment options with uncertainty in climate policy," Energy Economics, Vol.30, pp. 1933-1950, July 2008.

[6] Bartłomiej Igliński, Roman Buczkowski, Anna Iglińska, Marcin Cichosz, Grzegorz Piechota, Wojciech Kujawski, "Agricultural biogas plants in Poland: Investment process, economical and environmental aspects, biogas potential," Renewable and Sustainable Energy Reviews, Vol.16, pp. 4890-4900 September 2012.

[7] Kaveh Khalili Damghani, Soheil Sadi-Nezhad, M.B. Aryanezhad, "A modular Decision Support System for optimum investment selection in presence of uncertainty: Combination of fuzzy mathematical programming and fuzzy rule based system," Expert Systems with Applications, Vol.38, pp. 824-834, January 2011.

[8] Peter Miller, Ted O'Leary, "Mediating instruments and making markets: Capital budgeting, science and the economy," Accounting, Organizations and Society, Vol.32, pp. 701-734, OctoberNovember 2007.

[9] Ethan Ilzetzki, Enrique G. Mendoza, Carlos A. Végh, "How big (small?) are fiscal multipliers?" Journal of Monetary Economics, Vol.60, pp. 239-254, March 2013.

[10] Matt Croucher, "Potential problems and limitations of energy conservation and energy efficiency," Energy Policy, Vol.39, pp. 5795-5799, October 2011. 